\title{
ANALYSIS OF DIFFERENT LEVEL OF RESILIENCE IN FARMING COMMUNITIES IN FLOOD DISASTER-PROPOSED AREA IN BOJONEGORO REGENCY
}

\author{
Bambang Sigit Widodo ${ }^{1}$, Nur Isroatul Khusna ${ }^{2}$, Waode Yunia Silviariza ${ }^{3}$ \\ ${ }^{1)}$ Department of Geography Education, Faculty of Social Sciences and Law, \\ Universitas Negeri Surabaya \\ ${ }^{2}$ Department of Tadris Social Studies, Universitas Sayyid Ali Rahmatullah Tulungagung \\ ${ }^{3}$ Doctoral Student of Geography Education, Faculty of Social Sciences, \\ Universitas Negeri Malang
}

\begin{abstract}
Abstrak: Penelitian ini bertujuan untuk mengetahui tingkat resiliensi pada masyarakat petani di wilayah rawan bencana banjir yang meliputi Kecamatan Bojonegoro, Kecamatan Balen, dan Kecamatan Trucuk. Jenis penelitian ini adalah kuantitatif dengan menggunakan pendekatan survey. Sampel dalam penelitian ini berjumlah 153 responden dengan kriteria yang telah ditentukan yaitu petani dengan kepemilikan lahan kurang dari 1 hektar. Pengumpulan data menggunakan instrumen resiliensi yang dikembangkan oleh CD-RISC, dan selanjutnya dimodifikasi oleh peneliti yang disesuaikan dengan karakteristik responden. Analisis data menggunakan uji one way anova. Hasil penelitian menunjukkan nilai $\mathrm{p}<0.001$, sehingga terdapat perbedaan yang signifikan antara tingkat resiliensi pada ketiga wilayah dengan nilai tertinggi kecamatan bojonegoro yaitu 112.805, yang artinya memiliki tingkat resiliensi lebih baik dibandingkan Kecamatan Balen dan Trucuk. Frekuensi di kecamatan Bojonegoro menerima banjir > 2 kali dalam setahun menjadikan masyarakat di wilayah ini memiliki kemampuan beradaptasi, sehingga resiliensinya menjadi lebih baik.

Kata kunci: resiliensi, petani, bencana banjir
\end{abstract}

\begin{abstract}
This study aims to determine the level of resilience in farming communities in flood-prone areas which include Bojonegoro District, Balen District, and Trucuk District. This type of research is quantitative using a survey approach. The sample in this study amounted to 153 respondents with predetermined criteria, namely farmers with land ownership of less than 1 hectare. Collecting data using a resilience instrument developed by CD-RISC, and then modified by the researcher according to the characteristics of the respondents. Data analysis used one way ANOVA test. The results showed a $p$ value $<0.001$, so there was a significant difference between the levels of resilience in the three regions with the highest value in the Bojonegoro sub-district, namely 112.805, which means that it has a better resilience level than Balen and Trucuk Districts. The frequency in which the Bojonegoro sub-district receives floods $>2$ times a year makes the people in this area have the ability to adapt, so that their resilience is better.
\end{abstract}

Keywords: resilience, farmers, flood disaster

\section{A. INTRODUCTION}

Indonesia is a country prone to floods and landslides. The factors that cause floods and landslides are not only heavy rains, but also from the resultant impacts of global climate change, changes in land use, increasing population, urbanization, poverty, vulnerability, river silting and so on

Corespondency address : 
which causes flooding and landslides to increase. Based on the disaster map owned by the National Disaster Management Agency in Indonesia, there are 315 regencies/cities located in moderate-high hazard areas from flooding. There is a population of 61 million people in the area. As for landslides, there are 274 regencies/cities that are in moderate-high hazard areas from landslides with a population of 40.9 million people.

Flood disaster is a global phenomenon that causes widespread damage, is economically detrimental, and even kills human life (Asian Disaster Reduction Center, 2015). Every flood event has caused tremendous losses to people's lives and property, both in economic and social aspects. Most of the flood victims had to deal with destroyed houses, farms and agricultural products. Sometimes, the severity increases to a drastic level of poverty (Supattra, 2020).

Even in areas that are prone to flooding, the impact will actually decrease the selling value of their houses and land (Dimuthu, 2020). Several studies have shown that housing prices respond to flood risk. Other research also shows that homes located in areas that are more prone to future flooding are selling at significant discounts. Likewise with research conducted by Bernstein et al. (2019) and Baldauf et al. (2020) show that coastal properties that are less vulnerable to sea level rise are selling at a premium. Another study by Zhang and Leonard (2019) showed that houses affected by major floods were sold at discounted prices after the incident. Bojonegoro Regency is one of the areas prone to flooding. The main cause of flooding is the inability of the Bengawan Solo river to accommodate the rain discharge that occurs. Bojonegoro is a quite unique area. During the dry season, the area is dry, but always floods during the rainy season.

Bojonegoro Regency has 28 subdistricts with 14 sub-districts located in the Bengawan Solo watershed, namely Margomulyo, Ngraho, Padangan, Kasiman, Purwosari, Malo, Kalitidu, Trucuk, Dander, Bojonegoro, Kapas, Balen, Kanor, and Baureno sub-districts (BPS Regency Bojonegoro , 2019). The flood that occurred in Bojonegoro Regency had a broad impact on infrastructure damage, the community's economy and the submergence of agricultural land which resulted in farmers experiencing losses because they could not use their fields for agriculture. However, the flood disaster that always comes regularly every year during the rainy season has strengthened the mental and endurance or resilience of the farmers to be able to adapt to floods. Farming communities cannot do much to fight against nature, so their resilience is 
to accept the situation or surrender, and continue to adapt to the conditions that occur. Community vulnerability to disasters will tend to increase in people living in disaster-prone areas. People who are vulnerable and bear the burden will suffer five times as much as a disaster. In these conditions, the community must adapt to the environment in which they live which has a risk of disaster.

Farming communities are of course part of the community affected by the flood disaster, where their agricultural land must be submerged in water for a long period of time. Farming communities of course need to adapt to these conditions, so that the sustainability of their lives can continue.

The ability of people to survive or adapt to a change or pressure is called resilience. Changes or pressures that threaten and disrupt people's lives are in the form of disasters. The ability of a country, society and household to manage change by maintaining or changing their standard of living to deal with the stresses and shocks caused by disasters is called disaster resilience.

Disaster resilience is important to implement because it can reduce exposure and vulnerability in high-risk areas of disasters and their impacts before a disaster occurs, and can reduce costs and consequences of disasters. In addition, resilience aims to increase human knowledge to utilize important resources, information and services so that their livelihoods can increase.

Strengthening disaster resilience is very important in achieving the Sustainable Development Goals (SDGs) in 2030. One of the SDGs goals, namely climate change management, will be achieved if resilience and adaptability to natural disasters in all countries can be improved. In addition, disaster resilience plays a role in ensuring healthy lives and supporting welfare for all at all ages by strengthening the capacity of all countries, especially developing countries to carry out early warning, reduction and management of national and global health risks.

Resilience or resilience to disasters also plays a role in realizing cities and settlements that are inclusive, safe, resilient and sustainable in an area. This study aims to see the level of resilience, especially in farming communities who live in flood-prone areas. The locations of this research are Bojonegoro District, Trucuk District and Balen District.

\section{B. METHOD}

The type of the research is quantitative using a survey approach. According to Sugiyono (2017) what is meant by survey research is research conducted on large or small populations, but the data studied are data from 
samples taken from that population, so that relative events, distributions, and relationships between sociological variables are found. as well as psychological. Thus, in survey research, it is important to determine how many samples to take.

The samples taken in this study amounted to 153 respondents with details of 40 Bojonegoro Subdistricts, 66 Trucuk Subdistricts, and 47 Balen Subdistricts. Sampling was based on the population proposition in 3 subdistricts and the consideration of the number of farmers who had agricultural land $<1$ hectare.

Determination of the sample with farmers who have less than 1 hectare of land because the researchers have a consideration that the impact of flooding will be more felt on small farmers or farm laborers. Meanwhile, to collect data using a resilience instrument developed by Connor and Davidson Resilience Scale (CD-RISC) and subsequently modified according to the needs of this study. This instrument consists of 25 criteria that are the basis for measuring the level of resilience and with a weighted assessment score using a 0-4 of the Linkert scale.

The research data analysis technique uses the ANOVA test and is processed with SPSS 25. ANOVA or analysis of variance is one of the comparative tests used to test the difference in the average data of more than 2 groups. Because in this study the researcher wants to make a comparison between 3 regions, the use of the Anova test is appropriate, with the following requirements: the data is normally distributed, the variance between groups must be homogeneous, and the sample must be independent where the value in one group does not depend on other groups. One-way ANOVA test analysis was carried out using the following test procedure:

1. $\mathrm{H} 0=$ there is no difference in the level of resilience between farming communities in the 3 regions.

2. $\mathrm{H} 1=$ there is a difference in the average level of resilience between farming communities in the 3 regions.

3. The level of significance is $95 \%$ with a standard error of 0.05

4. Decision making $\mathrm{HO}$ is rejected if $\mathrm{p}$ value $>0.05$, and $\mathrm{H} 1$ is accepted if $p$ value $<0.05$

\section{RESULT AND DISCUSSION C.1. RESULT}

The three areas referred to in this study includes are Balen District, Bojonegoro District and Trucuk District. Furthermore, based on the one way ANOVA test, the results are obtained as shown in Table 1. 
Tabel 1. ANOVA - Resilence Levels

\begin{tabular}{lcrcccc}
\hline \multicolumn{1}{c}{ Cases } & Sum of Squares & df & Mean Square & F & p & $\boldsymbol{\eta}^{\mathbf{2}}$ \\
\hline Sub District & 14115.91 & 2 & 7057.96 & 74.95 & $<.001$ & 0.500 \\
\hline Residuals & 14124.77 & 150 & 94.17 & & &
\end{tabular}

Source : Calculation Result

It is known that the $\mathrm{p}$ value < 0.001 , which means that the $\mathrm{p}$ value is less than 0.05 so that $\mathrm{H} 0$ is rejected and $\mathrm{H} 1$ is accepted. Therefore, statistically it can be said that there is a significant difference between the level of resilience in farming communities in Bojonegoro, Balen and Trucuk sub-districts. While the value of the difference between the three regions can be seen in the table and scree plot image below.

Tabel 2. Differences in Resilience Levels

\begin{tabular}{lccc}
\hline Sub Districts & Mean & SD & N \\
\hline Balen & 97.69 & 4.14 & 45 \\
\hline Bojonegoro & 112.81 & 13.42 & 41 \\
\hline Trucuk & 89.25 & 9.67 & 67 \\
\hline & & & Source : Calculation Result
\end{tabular}

Based on the Table 2, it is known that Bojonegoro sub-district has the best level of resilience among 2 other subdistricts, Trucuk and Balen. Based on these data, it shows that Bojonegoro has an average score of 112.81, Balen 97.69, and Trucuk 89.25. When viewed from the characteristics of the frequency of floods, Bojonegoro sub-district also has the highest average > 2. Meanwhile, Balen and Trucuk have a frequency of 1-2 times in the last 3 years.

Figure 1. also shows the level of resilience in farming communities between Bojonegoro, Balen, and Trucuk. Based on data analysis in this study, it can be concluded that there is a significant difference between the level of resilience in farming communities in Bojonegoro, Balen and Trucuk

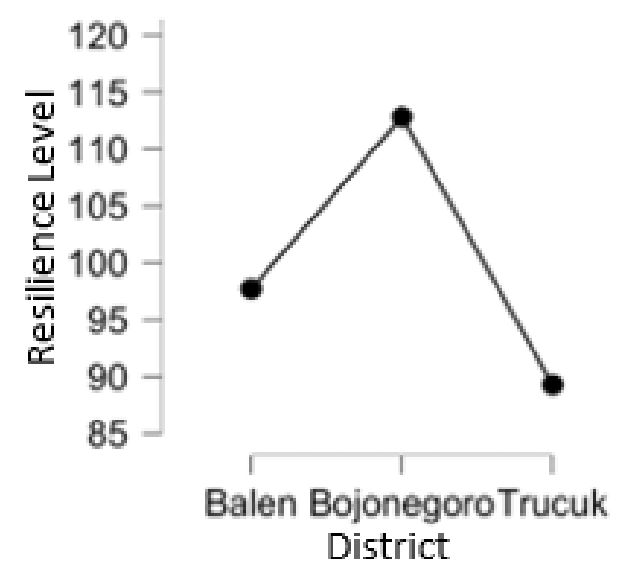

Figure 1. differences of resilience levels 
Farming communities in the Bojonegoro sub-district have the highest level of resilience compared to the other 2 sub-districts, namely Balen and Trucuk.

\section{C.2. DISCUSSION}

Based on the results and research findings, it can be concluded that there is a relevance between the findings and the theory of resilience where each individual will be able to rise from various kinds of problems or adversity due to the resilience factors in him. The resilience factor is also built because of the life experiences they have faced and also the level of knowledge they have. Therefore this will help them to survive the difficulties they experience, times of crisis in life and overcome things that can trigger stress and help individuals to rise up better than the previous situation so that the disaster events experienced previously can be used as valuable experience when disaster strikes again.

The tendency of the community to be used to these conditions, so that the more frequent flooding will strengthen the community's resilience level to be able to survive and look for strategies to deal with it. This is in accordance with what Gowan et al. (2014) said that the experience of a disaster will determine what actions will be taken when the disaster comes based on previous knowledge or experience. Flood events have a negative impact on people living in flood-prone areas, and this can cause great damage in terms of economic losses as well as human life. Recent studies have identified a trend of increasing flood frequency with the affected population in recent decades (Paprotny et al., 2018) and suggested that global warming will dictate the future growth of extreme flood events and associated damage (Dottori et al. , 2018).

Among the possible causes of flooding, overflowing river water needs special attention. This is very possible due to the occurrence of quite large sedimentation in the river flow so that the high discharge of rainwater cannot be accommodated in the river, as happened in the Bengawan Solo river. This is further exacerbated if the embankment that is holding back the swift flowing water collapses or is not strong enough to withstand the overflowing river water. A good embankment system can actually create comfort for people living in floodprone areas. In fact, the presence of defenses such as hydraulics can create a sense of security among people living in flood prone areas, resulting in the growth of settlements and reduced preparedness, and thereby increasing vulnerability in those areas (Di Baldassarre et al., 2015).

The community in Bojonegoro sub-district, which has a higher level of resilience compared to the other 2 sub- 
districts, does not mean that they are not depressed, because some of the respondents experienced trauma when the embankment burst and destroyed their houses. The incident certainly had a mental impact on the people affected by the flood disaster.

The findings of this study are also in line with Alderman who said that the losses due to flooding (both financial and non-financial) and the stress caused by these losses worsened the mental health condition of the community: respondents who were affected by severe flooding reported more depression, anxiety, and psychosomatic symptoms. (headaches, body aches) and are more likely to develop post-traumatic stress disorder.

The results of other studies also show that the experience of flooding has a negative impact on the psychological well-being of the community and at least in some studies led to an increase in the use of drugs (Fernandez et al., 2015). Sekulova and van den Beggh (2016) showed that the flood experience decreased life satisfaction up to 6 years after the flood event, and similar findings were also shown in their research by Von Möllendorff and Hirschfeld (2016).

Thus, this study is also similar to the findings of research in the field which shows that the frequency of people who experience floods more often, then the level of resilience is higher or better. In this context, resilience is shown by the preparedness of the people in Bojonegoro District to adapt when the rainy season arrives.

The resilience of the community in Bojonegoro District is relevant to several research findings conducted by several other researchers where it is said that floods often have negative mental consequences. However, not everyone affected by the floods is equally affected when it comes to mental health issues. Previous research has identified several factors that are thought to mediate or moderate the impact of flood experiences on mental health, including personal factors, flood characteristics, and social factors (Fernandez et al., 2015). Personal factors refer to individual-level characteristics such as socioeconomic characteristics and existing health problems but also the coping (cognitive) style that each person has (Ikizer et al., 2016) or their perceived self-efficacy. For example, a high level of ego resilience, i.e. an individual's capacity to successfully adapt to a stressor is positively associated with better mental health outcomes after a traumatic experience.

The high level of resilience in farming communities in the Bojonegoro sub-district also cannot be separated from the strong kinship or social relations. In other words, the social capital owned by 
the farming community has strengthened their enthusiasm to be able to face the annual flood disaster together. According to Dittrich (2016) social factors refer to general or hazard-related social structures that result in the social support needed to cope with flood losses (Bubeck and Thieken, 2018).

Many social actions such as fundraising, flood care actions, and so on are an indication of the strong social support for the Indonesian people. Existing empirical evidence shows that social support is beneficial for mental health conditions after a flood disaster.

Masson research demonstrates the importance of constructing social support for improving our understanding of how people psychologically cope with the negative consequences of natural disasters such as floods. This may be somewhat surprising considering that flooding is a collective phenomenon that can usually only be controlled with collective efforts. From this perspective, it seems quite clear that the perception of communities themselves as more resilient to natural disasters is associated with less negative mental health outcomes at the individual level, as Masson suggests in his research.

Social support is needed by individuals in order to become strong and able to solve every problem in life. So that individuals are able to reduce negative risks which can harm and affect the activities of life. The effect of social support on the resilience of the individual concerned should be an important consideration. Individual those who receive social support from family, friends or their environment will be more capable face difficulties or difficulties than individuals who receive less support them. Many studies have found that social support has a relationship positive for resilience. Social support is an important factor to build resilience youth in many countries. In addition, Ariviyanti and Pradoto (2014) also found that there are three the most influential factor in increasing community resilience in the Tanjung Emas village Semarang. The three factors are the elevation of the house, the elevation of the road, and the presence of disaster response social organization.

Thus, it can be concluded that social support is important as an effort to strengthen the mentality of the farming community affected by the flood disaster, so that they can face the disaster well and be better prepared.

\section{CONCLUSION}

The level of resilience in farming communities is strongly influenced by the experiences received or experienced by them and the social support that exists in the community. The ability to survive 
well can be done in farming communities that do have a higher frequency of flooding, and in this study it was shown in farming communities in Bojonegoro sub-district. From the 3 areas studied, the results showed a significant difference in the level of resilience with a $p$ value of $<$ 0.001, and Bojonegoro District had the best level of resilience compared to Balen and Trucuk Districts.

\section{BIBLIOGRAPHY}

Ariviyanti, N., \& Pradoto, W. (2014). Faktor-faktor yang meningkatkan resiliensi masyarakat dalam menghadapi bencana rob di kelurahan Tanjung Emas Semarang. Teknik Perencanaan dan Kota , vol.3, no.1, 993-1002.

Asian Disaster Reduction Center. (2015). Natural disaster data book. Japan: Asian Disaster Reduction Center (ADRC).

Baldauf, M., Garlappi, L., \& Yannelis, C. (2020). Does climate change affect real estate prices? Only if you believe in it. The Review of Financial Studies, 33(3), 12561295.

Begg, C., Ueberham, M., Masson, T., and Kuhlicke, C. (2016) In- teractions between citizen responsibilization, flood experi- ence and household resilience: Insights from the 2013 flood in Germany, Int. J. Water.
Resour. D., 33, 591-608, https://doi.org/10.1080/07900627. 2016.1200961.

Bernstein, A., Gustafson, M. T., \& Lewis, R. (2019). Disaster on the horizon: The price effect of sea level rise. Journal of Financial Economics, 134(2), 253-272.

Bubeck, P. and Thieken, A. H. (2018). What helps people recover from floods? Insights from a survey among flood-affected residents in Germany, Reg. Environ. Change, 18 , 287-296, https://doi.org/10.1007/s10113017-1200-y.

Di Baldassarre, G., Castellarin, A., and Brath, A. (2015). Analysis of the effects of levee heightening on flood propagation: example of the River Po, Italy, Hydrolog. Sci. J., 54, 1007-1017.

Dittrich, R., Wreford, A., Butler, A., and Moran, D. (2016). The impact of flood action groups on the uptake of flood management measures, Climatic Change, 138, 471-489, https://doi.org/10.1007/s10584016-1752-8.

Fernandez, A., Black, J., Jones, M., Wilson, L., Salvador-Carulla, L., Astell-Burt, T., and Black, D. (2015) Flooding and mental health: A systematic mapping 
review, PloS One, 10, e0119929, https://doi.org/10.1371/journal.po ne.0119929.

Ikizer, G., Karanci, A. N., and Ikizer, G. (2016). Exploring Fac- tors Associated with Psychological Resilience Among Earth- quake Survivors from Turkey, J. Loss Trauma, 21, 384-398, https://doi.org/10.1080/15325024. 2015.1108794.

Masson, T., Bamberg, S., Stricker, M., and Heidenreich, A. (2019). "We can help ourselves": does community resilience buffer against the negative impact of flooding on mental health?, Nat. Hazards Earth Syst. Sci., 19, 2371-2384, https://doi.org/10.5194/nhess-192371-2019.

Paprotny, D., Sebastian, A., MoralesNápoles, O., and Jonkman, S. N. (2018). Trends in flood losses in Europe over the past 150 years, Nat. Commun., 9, 1985, https://doi.org/10.1038/s41467018-04253- 1.

Sekulova, F. and van den Bergh, J. C. J. M. (2016). Floods and happiness: Empirical evidence from Bulgaria, Ecol. Econ., 126, 51- 57, https://doi.org/10.1016/j.ecolecon. 2016.02.014.
Sugiyono. (2017). Metode Penelitian Kuantitatif, Kualitatif, dan R\&D. Bandung : Alfabeta

Von Möllendorff, C. and Hirschfeld, J. (2016). Measuring im- pacts of extreme weather events using the life sat- isfaction approach, Ecol. Econ., 121, 108-116, https://doi.org/10.1016/j.ecolecon. 2015.11.013.

Zhang, L., \& Leonard, T. (2019). Flood hazards impact on neighborhood house prices. The Journal of Real Estate Finance and Economics, 58(4), 656-674. 